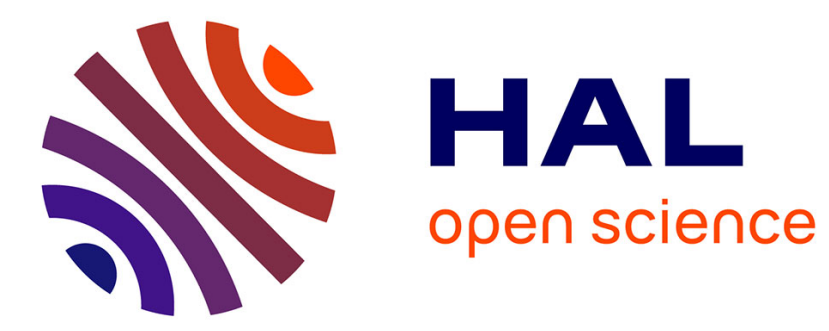

\title{
EXTRINSIC ORIGINE OF RECOMBINATION CENTRES AT GRAIN BOUNDARIES IN P TYPE SILICON BICRYSTALS
}

\author{
M. Pasquinelli, N. M'Gaffad, H. Amanrich, L. Ammor, S. Martinuzzi
}

\section{- To cite this version:}

M. Pasquinelli, N. M'Gaffad, H. Amanrich, L. Ammor, S. Martinuzzi. EXTRINSIC ORIGINE OF RECOMBINATION CENTRES AT GRAIN BOUNDARIES IN P TYPE SILICON BICRYSTALS. Journal de Physique Colloques, 1989, 50 (C6), pp.C6-159-C6-159. 10.1051/jphyscol:1989619 . jpa00229650

\section{HAL Id: jpa-00229650 https://hal.science/jpa-00229650}

Submitted on 1 Jan 1989

HAL is a multi-disciplinary open access archive for the deposit and dissemination of scientific research documents, whether they are published or not. The documents may come from teaching and research institutions in France or abroad, or from public or private research centers.
L'archive ouverte pluridisciplinaire HAL, est destinée au dépôt et à la diffusion de documents scientifiques de niveau recherche, publiés ou non, émanant des établissements d'enseignement et de recherche français ou étrangers, des laboratoires publics ou privés. 


\title{
EXTRINSIC ORIGIN OF RECOMBINATION CENTRES AT GRAIN BOUNDARIES IN P TYPE SILICON BICRYSTALS
}

\author{
M. PASQUINELLI, N. M'GAFFAD (1), H. AMANRICH, L. AMMOR and S. MARTINUZZI
}

\begin{abstract}
Laboratoire de Photoélectricité des semi-Conducteurs, Faculté des Sciences et Techniques de Marseille Saint-Jérôme, Université d'Aix-Marseille III, F-13397 Marseille Cedex 13, France
\end{abstract}

The origin of recombination centres at grain boundaries (G.B.'s) $\sum 9$ and v13 in "CZ" grown bicrystals, doped. with $10^{15} \mathrm{~cm}^{-3}$ boron atoms, has been investigated. L.B.I.C. scan maps at $\lambda=940 \mathrm{~nm}$ and global capacitive measurements ( $\mathrm{C}-\mathrm{V}$ plots, DLTS) applied to the space charge region of G.B.'S, have been used. The first technic allows the local determination of interfacial recombination velocity $\mathrm{s}$, while the second one leads to average values of energy $E_{\mathrm{T}}$, density $\mathrm{N}_{\mathrm{T}}$ and cross section $\sigma_{\mathrm{T}}$ of recombination centres of G.B.'s. Doping a.toms profiles can also be obtained within G.B.'s.

The results indicate that the two types of G.B.'s, and particularly $\Sigma 9$ have not a noticeable recombination activity in the as grown bicrystals. Annealings at temperatures about $600^{\circ} \mathrm{C}$, at least, during several hours are needed to activate $\Sigma 13 \mathrm{G} . \mathrm{B}$. 's heterogeneously.

The average values of $E_{T}$ obtained by DLTS are in the range between 0.4 and $0.5 \mathrm{ev}$. For such values, it was reported that oxygen or $\mathrm{SiO}_{\mathrm{x}}$ precipitates could be the source of these deep levels $/ 1 /$.

In addition, Batistella et al. /2/ have observed that the activation of G.B.'s is heterogeneous and due to localized recombining clusters.

As the investigated "CZ" silicon contains a large amount of oxygen, it could be assumed that oxygen segregation by G.B.'s explains the enhancement of recombination activity during the annealings. $\Sigma 9$ G.B.'s remain poorly recombining, probably because dopant atoms have been segregated during crystal growth, as suggested by the doping profile within a G.B. given by figure 1 .

\section{References}

$/ 1 /$ K. SCHMALZ, F.G. KIRSCHT, H. KLOSE, H. RICHTER and K. TITTELBACK-HELMRICH, Phys. Status Solid (a) 100 p.567 (1987).

$12 / \mathrm{F}$. BATISTELLA et A. ROCHER, Proc. of $6^{\text {th }}$ European Photov.sol.En.Conf. London, April 1985, pp.113-117.

Fig.1. Net density of negative charges in the space charge region of $\Sigma 9 \mathrm{~GB}$ after annealing at $900^{\circ} \mathrm{C}$ during $24 \mathrm{H}$.

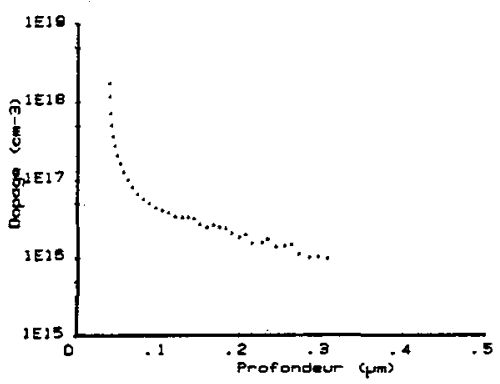

(1) on leave of the E.N.S. of Takaddoum-Rabat, Maroc 